\title{
Giardia and Other Parasites of Small Mammals in Grand Teton National Park
}

\author{
William D. O'Dell + Raychel A. Watkins + SuZanne E. Moshier \\ DEPARTMENT OF BIOLOGY — UNIVERSITY OF NEBRASKa \\ ОMAHA \\ Aelita J. Pinter \\ Department of Biological ScIENCES — University of New OrLeANS \\ New ORLEans
}

\section{$\downarrow \quad$ Project Objectives}

The objectives of this study are to document effects of parasitism on vole populations, and to determine the potential of small mammals of Grand Teton National Park to serve as reservoirs of human parasites.

Specific goals for this year were:

1. to continue surveying small mammals for Babesia microti;

2. to collect and identify ticks found with these animals;

3. to determine if Ixodes eastoni is a tick vector of $B$. microti;

4. to determine the incidence of Campylobacter spp. in these small mammals; and

5. to continue documentation of the occurrence of Giardia as an intestinal parasite of the montane vole.

\section{$\downarrow$ MethodS}

Animals were trapped in Sherman live-traps at one of six sites within the boundaries of the Grand Teton
National Park. They were anesthetized before an incision was made into the pericardial cavity and blood collected from the heart into several heparinized capillary tubes. Thin blood smears were fixed in $100 \%$ methanol, and stained with Wright's Giemsa stain. Hematocrits were recorded as the mean of two separate determinations. Reticulocyte counts were done with a Becton-Dickinson Unopette Test 5821. The spleen and liver were removed, weighed and measured. Impression smears of the spleen were also fixed in methanol and stained with Wright's Giemsa stain.

Blood smears were each examined for the presence of Babesia a minimum of 15 minutes. If no parasitized cells were found, the specimen was scored as negative. The number of parasitized erythrocytes in a sample of 1000 was counted and recorded as percent parasitemia. The morphology of the erythrocytes was noted. Polychromasia was graded on a scale from a trace to 4 plus.

Ticks found attached to the animals were removed and stored in 10\% buffered formalin ( $\mathrm{pH} \mathrm{7.0).} \mathrm{They}$ were later transferred to a solution of water and detergent (Alconox), and cleaned in an ultrasonic washer for 20 minutes. After rinsing in tap water, they were transferred to $50 \%$ ethanol, dehydrated in an 
ascending series of ethanols, placed in acetone for one hour, critical point dried, and sputter coated with gold-paladium. They were examined on an ISI Alpha 9 scanning electron microscope and photomicrographs were recorded on Polaroid 55 film.

\section{$\downarrow \quad$ RESULTS}

$B$. microti was identified on the basis of the morphology of the parasite. The incidence of Babesia microti in Microtus montanus from Grand Teton National Park for the years 1987 through 1990 is given in Table 1. In addition, 5 of $12 \mathrm{M}$. pennsylvanicus and 1 of 3 Arvicola richardsoni were parasitized by $B$. microti. None of the 39 Peromyscus leucopus was infected.

The spleens of all infected animals were enlarged $(\mathrm{P}<0.001)$. The spleens of $86.7 \%$ of uninfected animals measured less than $20 \mathrm{~mm}$ or greater in length; with $56 \%$ of these spleens measuring $30 \mathrm{~mm}$ or greater. The mean spleen size of 9 laboratory-reared M. montanus was $14.9 \pm 1.8 \mathrm{~mm}$ long by $4.4 \pm 0.5 \mathrm{~mm}$ wide. The mean size of spleens of infected wild animals $(32.0 \pm 6.8 \times 11.8 \pm 2.3 \mathrm{~mm})$ was about twice that of uninfected or laboratory-reared animals $B$. microti cells were sometimes observed in the stained spleen smears.

Reticulocyte numbers were greater in infected animals. Only $6.7 \%$ of the uninfected animals had reticulocyte levels greater than $10 \%$, while $48 \%$ of the infected animals had reticulocyte counts greater than $10 \%$.

Differences in hematocrit values were unremarkable. The mean hematocrit for uninfected animals was $49.5 \pm 3.3 \%$ packed cell volume, while the mean hematocrit for infected animals was actually slightly higher at $50.4 \pm 4.1 \%$.

Infections of a Hepatozoon sp. were concurrent with $B$. microti in $4 M$. montanus and in $3 M$. pennsylvanicus. A Trypanosoma infection was concurrent with $B$. microti in $1 M$. montanus. Two $M$. montanus had a triple infection of B. microti, Trypanosoma, and Hepatozoon. Six $M$. montanus were infected with Trypanosoma sp., while the bacterium, Grahamella sp., was found in the erythrocytes of 7 other $M$. montanus. Giardia sp. was found in $98 \%$ of the $M$. montanus. Nine ticks, Ixodes eastoni, 7 adult females and 2 nymphs, were removed from $M$. montanus.

Table 1.Incidence of Babesia microti in Microtus montanus from six sites within Grand Teton National Park.

$\begin{array}{lcccccccr} & \underline{1987} & & \underline{1988} & & \underline{1989} & & \underline{1990} & \\ \text { SITE } & \text { JULY } & \text { MAY } & \text { JULY } & \text { MAY } & \text { JULY } & \text { MAY } & \text { JULY } & \text { TOTAL } \\ \text { Cattleman's } & & 1 / 3^{*} & 1 / 1 & & & & & 4 / 5 \\ \text { Moose Calf } & & 6 / 7 & 2 / 2 & & 2 / 4 & & & 10 / 13 \\ \text { Depletion } & 3 / 13 & 4 / 10 & 1 / 15 & 3 / 4 & 5 / 6 & 8 / 15 & 12 / 35 & 36 / 98 \\ \text { Grid } & 6 / 14 & & 5 / 10 & & 4 / 13 & & 16 / 35 & 31 / 72 \\ \text { Tornado } & 2 / 3 & & 1 / 1 & 13 / 33 & 2 / 9 & & & 18 / 46 \\ \text { Bear Grass } & & 4 / 21 & & & & & 4 / 21\end{array}$

*Number of infected animals/total number trapped 


\section{$\downarrow \quad$ ConClusions}

The montane vole and the meadow vole are the primary reservoirs of Babesia microti in Grand Teton National Park. Splenomegaly and reticulocytosis are important diagnostic signs of babesiosis in montane voles. Hematocrit is not a reliable diagnostic tool. The voles are also the hosts for a number of other parasites, any or all of which must certainly impact on their health and survival. The white-footed mouse appears not to be a significant reservoir for $B$. microti in this ecosystem. Ixodes eastoni is the most likely candidate for the vector of Babesia. Transmission studies will be necessary to document this tick as the vector.

\section{$\downarrow$ Selected Bibliography}

Articles:

Pinter, A. J., W. D. O'Dell, and R. A. Watkins. 1988. Intestinal parasites of small mammals from Grand Teton National Park. J. Parasitol. 74:187-188.

Watkins, R. A., W. D. O'Dell, and A. J. Pinter. 1989. Redescription of flagellar arrangement in the duck intestinal flacellate, Cochlosoma anatis and description of a new species, Cochlosoma soricis n. sp. from shrews. J. Protozool. 36:555-559.
Papers:

Watkins, R. A., W. D. O'Dell, S. E. Moshier, and A. J. Pinter. 1989. Babesiosis in the Montane Vole, Microtus montanus. Annual Meeting, Nebraska Academy of Sciences, Lincoln, Nebraska.

Watkins, R. A., A. J. Pinter, S. E. Moshier, and W. D. O'Dell. 1990. Splenomegaly, Reticulocytosis, and Babesia microti in Natural Populations of the Montane Vole, Microtus montanus. Annual Meeting of the American Society of Mammalogists. 